\title{
Black-browed albatrosses, international fisheries and the Patagonian Shelf
}

\author{
D. Grémillet ${ }^{1, *}$, R. P. Wilson ${ }^{2}$, S. Wanless ${ }^{1}$, T. Chater ${ }^{3}$ \\ 'Centre for Ecology and Hydrology, Banchory Research Station, Hill of Brathens, Banchory, Kincardineshire AB31 4BY, \\ Scotland, UK \\ ${ }^{2}$ Institut für Meereskunde Kiel, Düsternbrooker Weg 20, 24105 Kiel, Germany \\ ${ }^{3}$ New Island, Falkland Islands, South Atlantic
}

\begin{abstract}
Albatrosses have among the most remarkable travelling capacities of any extant animal However, previous studies regarding their movements at sea have mainly focused on breeding birds commuting between the nest site and offshore feeding grounds. In this study, we compare the movement patterns and at-sea activity of breeding and inter-breeding black-browed albatrosses Diomedea melanophris from the Falkland Islands. Data were recorded via global location and activity sensors for 26 incubating birds (during single foraging trips lasting $6.8 \mathrm{~d}$ on average) and 6 inter-breeding individuals (during non-5top offshore journeys of $127.5 \mathrm{~d}$ on average). Our results showed that foraging black-browed albatrosses utilise vast offshore areas (the average foraging area was $102000 \pm$ $132000 \mathrm{~km}^{2}$ by incubating birds and $1552000 \pm 970000 \mathrm{~km}^{2}$ by inter-breeding birds). However, mean foraging range was similar in both groups $(691 \pm 330 \mathrm{~km}$ and $680 \pm 192 \mathrm{~km}$ by incubating and interbreeding birds, respectively) as were their core foraging areas and their at-sea activity patterns. Our results thus indicate that black-browed albatrosses from the Falkland Islands, which represent the largest albatross population world-wide (ca 800000 individuals), mainly rely on marine resources available within the Patagonian Shelf area. Although this highly productive continental shelf is the largest of the Southern Hemisphere, rapid development of industrial fisheries currently results in the removal of over 1.4 million tonnes of fish and squid per year in this zone. As our data also show significant spatio-temporal overlap between human and albatross fishing activities within the Patagonian Shelf. we anticipate major detrimental effects on the albatross population in terms of competition for food and additional mortality caused by bird bycatch.
\end{abstract}

KEY WORDS: Albatross - Global location sensors · Foraging range $\cdot$ Patagonian Shelf $\cdot$ Fisheries

\section{INTRODUCTION}

The scientific term 'ecology' was defined in 1866 by the eminent phylogenist and pioneer marine biologist Enst Haeckel (Haeckel 1866). Since then, generations of scientists have been involved in a research field which has led to a new, holistic view of our environment. However, although these investigations confirmed the primal importance of aquatic ecosystems in the biosphere as postulated by Haeckel (Field et al. 1998, Nihoul 1998, Taylor \& Planque 1998), a major

•E-mail:dgrem@ceh.ac.uk imbalance exists between the amount of knowledge accumulated about terrestrial ecosystems and the relative lack of information about major energy fluxes within aquatic ecosystems (Greenwood 1992, Croll et al. 1998, Goni 1998). This particularly concerns the higher trophic levels in marine food chains (Larkin 1996, Bowen 1997), as many marine top predators are per se large, off-shore animals which cannot be easily studied either in the field or in the laboratory (Butler $\&$ Jones 1997). However, wherever technological advances (Croxall 1995) have allowed extensive field studies of the behaviour and energetics of marine toppredators, surprising animal performances have been recorded. In most diving species for example, dive 
depths registered by animal-mounted devices greatly exceeded former predictions, showing unsuspected abilities to search for prey at great depth (Kooyman et al. 1971, Gales \& Mattlin 1997, Zavalaga \& Jahncke 1997. Hooker \& Baird 1999). In addition to these extended vertical movements, a similar trend applies to large-scale horizontal movements (i.e. central-place and free-ranging foraging, migration or dispersal): although previous workers already suspected that individual top-predators exploit resources over extended areas, it is only the recent development of satellite tracking which has confirmed the astonishing travelling capacities of many marine predators (McConnell \& Fedak 1996, Bost et al. 1997, Block et al. 1998, Luschi et al. 1998). A primal example of this are albatrosses, which display the largest foraging areas so far recorded in any extant central-place forager. During the breeding season wandering albatrosses Diomedea exulans, for example, may travel $15000 \mathrm{~km}$ over the Southern Ocean during a single feeding trip (Jouventin \& Weimerskirch 1990). This performance is made possible by dynamic-soaring, a flight technique which enables these birds to travel at low energy costs for extended periods (Pennycuick 1989). Satellite tagging has also allowed the discovery of similarly vast foraging areas in procellariiforms (Weimerskirch \& Robertson 1994, Sagar \& Weimerskirch 1996, Veit \& Prince 1997, Weimerskirch et al. 1999). However, these studies are technically linked to the breeding season since, although platform transmitter terminals such as those used in satellite tracking research can be duty cycled to allow positions to be determined for longer periods, as yet, no suitable method has been developed for their long-term attachment ( $\mathrm{H}$. Weimerskirch pers. comm.). Thus, most studies are likely to provide a skewed view of the behaviour and energetics of the studied seabird species and to lead to potential misconceptions about their ecological status. In this paper, we present the first study involving bird-mounted data loggers which directly compares the foraging behaviour of a large offshore avian predator, the black-browed albatross Diomedea melanophris, both during and outside of its breeding season. We use these data to test a major prediction of optimal foraging theory regarding central place foragers. Our findings have important conservation implications.

\section{METHODS}

We studied black-browed albatrosses Diomedea melanophris on New Island (51 $43^{\prime} \mathrm{S}, 61^{\circ} 18^{\prime} \mathrm{W}$ ), West Falklands during the incubation phase (October to December 1996) and the inter-breeding period (April to September 1997). We used 3 different types of logging units: (1) SBT200 3-channel loggers $(55 \times 24 \times$ $12 \mathrm{~mm}, 25 \mathrm{~g}$, i.e. $0.8 \%$ of body mass, 1 Mbyte memory, 8 bit resolution; Zelcon Technic Pty Ltd, Technopark Dowsings Point, Glenorchy, Tasmania 7010, Australia) recording light intensity (with a photo-voltaic cell producing a response for approximate light intensity values between 1 and 50000 lux in ca 200 lux steps), temperature $\left(0.1^{\circ} \mathrm{C}\right.$ resolution) and hydrostatic pressure; (2) LTD-100 3-channel loggers (44 × $18 \mathrm{~mm}$ diam., 16 g, i.e. $0.5 \%$ body mass, 1.5 Mbyte memory, 12 bit resolution; Lotek Marine Technologies Inc., 114 Cabot street, St. John's, Newfoundland A1C 1Z8, Canada), recording light intensity (with a photo-sensitive cell producing a response for approximate light intensity values between 1 and 80000 lux in ca 20 lux steps), temperature $\left(0.1^{\circ} \mathrm{C}\right.$ resolution) and hydrostatic pressure; and (3) DKLog 600 6-channel loggers (9 to $20 \mathrm{~mm}$ thick, 3 to $65 \mathrm{~mm}$ wide, $145 \mathrm{~mm}$ long, $110 \mathrm{~g}$, i.e. $3.6 \%$ body mass, 2 Mbyte memory, 16 bit resolution; Driesen + Kern GmbH, Am Hasselt 25, 24576 Bad Bramstedt, Germany), recording light intensity (with a photo-sensitive cell producing a response for light intensity values between 0.1 and 100000 lux in ca 2 Iux steps), temperature $\left(0.03^{\circ} \mathrm{C}\right.$ resolution), barometric pressure, flight speed and heading.

During the incubation period, the breeding colony was observed until a nest site was located at which adult birds were changing duties lone partner coming back to the nest and the other partner leaving the nest to forage at sea). Shortly before completion of such a change-over, the single egg was carefully removed and the off-duty bird was captured and equipped with one of the devices described above. The returning bird then quickly occupied the empty nest, and the egg was set back into the nest for further incubation. SBT200 and LTD-100 loggers were attached to 2 Darvic foot rings ( $20 \mathrm{~mm} \times 18 \mathrm{~mm}$ internal diameter, $2 \mathrm{~mm}$ thick). The DKLog600 units were taped to the back feathers of the birds following Wilson et al. (1997) using 6 to 8 strips of Tesa tape. All nest sites were checked twice daily after the equipped birds went to sea. These individuals were recaptured and the devices removed after completion of a single foraging trip. In addition, 20 unequipped, incubating birds were dye-marked on the top of the head (one spot of $\mathrm{ca} 5 \mathrm{~cm}$ diameter) and the length of their foraging trips monitored via checks performed every $12 \mathrm{~h}$. Trip lengths assessed in this way were compared to trip lengths recorded for instrumented birds $( \pm 12 \mathrm{~h}$ ), so as to provided a test of potential device effects.

Towards the end of the chick-rearing period (April 1997), a second set of birds was equipped with ringmounted. SBT200 and LTD-100 archival units. In this case, breeding adults were caught as they returned to 
the nest to feed pre-fledging chicks. The devices were attached for long-term deployment to the foot with Tesa tape and with 1 or 2 cable ties. They were recovered in September and October 1997, as the birds returned to their nests after the inter-breeding period.

Geolocation. Data on light intensity stored by the loggers were analysed using the programme MULTITRACE (Jensen Software Systems, Lammerzweg 19. 24235 Laboe, Germany). Initially calibrations during which the units were placed outside at New Island for a number of days were performed to determine threshold values corresponding to the local time of dawn and dusk (considered to occur at a sun angle of $4.9^{\circ}$, see Wilson et al. 1999). These thresholds were then used in the analysis of the data derived from the devices deployed on free-living birds. The precise Greenwich Mean Time at which the thresholds occurred was used to determine day length and night length (as the period elapsed between dawn and dusk and vice versa) and the precise Greenwich Mean Time of midday and midnight calculated from the mid-point between dawn and dusk and vice versa, respectively. Algorithms were used to determine latitude by consideration of day length with respect to the day of the year and to determine longitude by consideration of the timing of mid-day and midnight (see Wilson et al. 1999 for details). The algorithms used corrected for errors incurred due to birds undergoing extensive movement between dawn and dusk by examining the total number of hours per day, which should, in the absence of movement, approximate to $24 \mathrm{~h}$ (Wilson et al. 1999).

There are many factors which may contribute to errors when light is used in logging units for deriving positional fixes. Among these are variations in cloud cover, variable sensor angle, dirt or feathers covering the sensor, inaccuracies in the quartz timer, insensitivity of the photocell, etc. Many of these errors, however, work against each other so that the total potential error is not represented by the sum of the parts. Many errors can be reduced by hardware measures, such as covering the sensor with a blue filter (which reduces the variation imposed by different cloud regimes), logging protocols (such as measuring at frequencies of $0.02 \mathrm{~Hz}$ or higher) and software corrections (such as smoothing positional fixes so that the effect of outliers due to stochastic processes is reduced) (for discussion see Walsh \& Everson 1999, Wilson et al. 1999). Ultimately, although calibrations can be made on land, as was done in our case, this does not accurately represent the case of the units on free-living, moving birds. Our calibrations showed that all units were, under ideal conditions, accurate to better than $90 \mathrm{~km}$. Wilson et al. (1995, in press) report that DKLog units give positional fixes generally to better than $40 \mathrm{~km}$, and a study involving a single king penguin equipped with a satellite tracking system and position measuring system via light gave a mean discrepancy of $32 \mathrm{~km}$ (C. A. Bost, R. P. Wilson, K. Puetz unpubl. data). In this latter case it should be noted that neither system could be considered as working optimally since both were deployed on a moving animal so that it is unrealistic to consider that the positionally superior satellite tracking system could be used as an accurate ground truth (see e.g. Burns \& Castelli 1998). Ultimately, some measure of the errors in our positional estimates can be alluded to by checking that birds had a derived course that led away from, and then to, the breeding island and by examining the extent to which our equipped birds apparently flew inland over coastal Argentina, something they never actually do. Consideration of this led us to believe that units may have incurred positional errors of up to $100 \mathrm{~km}$, although until a suitably small, highly accurate position determining system such as a derivative of global positioning systems (Kaplan 1996) is developed for tandem ground truthing, this will have to remain somewhat speculative.

Position data, density plots and work index. Positions calculated using light levels were projected using the Universal Transverse Mercator projection for the corresponding area (No. 21) in order to obtain absolute positions and distances in meters. Foraging area used by each bird as well as the corresponding increment plots were subsequently estimated using $95 \%$ concave polygons after Kenward \& Hodder (software package 'RangesV' Ver. 2.05, Kenward \& Hodder, ITE Furzebrook, UK).

Area utilisation in foraging for black-browed albatrosses was then assessed by plotting the number of observations (projected positions of birds at sea as calculated from light intensity data) made per unit seaarea using squares of $100 \mathrm{~km}^{2}$ as the fundamental unit. These plots were then mapped as topographic representations with $Z$ giving the density position fixes per unit area of the Patagonian Shelf (as defined by the $200 \mathrm{~m}$ isobath).

A 'work index' was finally calculated on a daily basis as the percentage of the maximum possible distance travelled by an albatross. The required mean maximum distance travelled per day was determined for wintering birds (i.e. our largest data set). The calculated index provides information on whether individual birds search for food within a distinct patch (low index) or rather travel long distances, searching for a more profitable area or foraging on occasional, highly scattered prey (high index)

At-sea activity. Wilson et al. (1995) previously concluded that temperature levels recorded by footattached data loggers (here SBT200 and LTD-100, see above) are lower and more stable when albatrosses are on the water, and thus data can be used to determine 
times when birds landed on the water and the durations of these intervals spent on the sea. We employed this technique in order to determine the activity patterns of birds foraging at sea. Due to the thermal inertia of the temperature sensors, a landing event could only be detected if the bird stayed in the water for longer than 1 min. This 1 min interval was also the accuracy with which times of landings and take-offs were determined.

Fishing statistics. We analysed 2 separate data sets recorded concomitantly with our study (October 1996 to September 1997). The first set, which was made available by the Falkland Islands Govermment, concerned fishing activities within the Falkland Islands Interim Conservation and Management Zone (FICZ, $280 \mathrm{~km}$ around the Falklands). The second set, which was provided by the Instituto Nacional de Investigaciones y Desarrollo Pesquero, Mar del Plata, Argentina, summarised catch statistics for the entire Patagonian Shelf area. Because the latter data gave the total catch for finfish and squid per month and degree of latitude, data from the FICZ and bird locations were summarised in the same way in order to enable direct spatio-temporal comparisons.

\section{RESULTS}

\section{Potential influence of the logging units on the birds' behaviour}

There was no evidence that albatrosses were adversely affected by any of the devices used when they were sitting on the nests or walking through the colony. Moreover, the mean length of foraging trips was not significantly different between equipped birds $(x=6.8 \pm 3.0 \mathrm{~d}$, range 2 to $15, \mathrm{n}=26)$ and control birds $(x=7.5 \pm 5.3 \mathrm{~d}$, range 3 to $25, \mathrm{n}=20 ; t=0.24, \mathrm{p}>0.5)$.

\section{Foraging patterns during the breeding season}

We equipped a total of 26 incubating birds (15 with SBT200, 9 with DKLog600 and 2 with LTD-100). All individuals were successfully recaptured after performing 1 foraging trip, and the logging devices including recorded data recovered. Birds reached a mean maximum distance of $1163 \mathrm{~km}(\mathrm{SD}=621, \mathrm{n}=26$ ) from the nest. They travelled faster on their way back to the nest $\left(450 \mathrm{~km} \mathrm{~d}^{-1}\right.$ during the last $24 \mathrm{~h}, \mathrm{SD}=220$, $\mathrm{n}=26)$ than during the middle part of the trip $(270 \mathrm{~km}$ $\mathrm{d}^{-1}, \mathrm{SD}=130, \mathrm{n}=26, t=3.44, \mathrm{p}<0.05$ ), but they were not faster during the first $24 \mathrm{~h}$ of the trip $\left(280 \mathrm{~km} \mathrm{~d}^{-1}\right.$, $\mathrm{SD}=220, \mathrm{n}=26$ ) than during the middle part of the trip $(t=0.3, p>0.05)$. All recorded fixes covered a total sea-

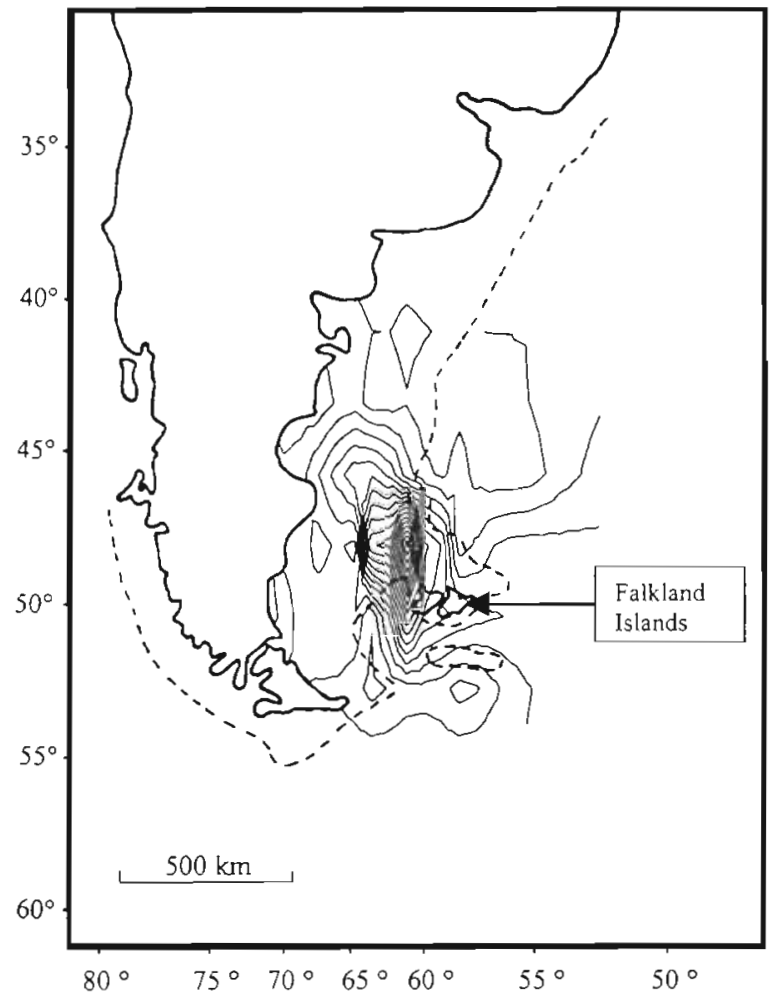

Fig. 1. Diomedea melanophris. Density plot showing the atsea distribution of 26 incubating black-browed albatrosses during single foraging trips performed off South America in October and November 1996. This topographic representation is based on positional fixes recorded every $12 \mathrm{~h}$ for foraging birds. The isolines give the density of positional fixes per surface area (for a contour interval of 3 fixes per unit area). The dotted line gives the $200 \mathrm{~m}$ depth contour

area of 1.19 million $\mathrm{km}^{2}$ (surface measured using a concave polygon, see 'Methods'). The incubating birds studied largely remained within the Patagonian Shelf area, with position fixes recorded from Mar del Plata in the north to Tierra del Fuego in the south (Fig. 1). Their core foraging area was situated north-west of the Falkland Islands (over $50 \%$ of all position fixes within 45 to $50^{\circ} \mathrm{S}$ and 60 to $70^{\circ} \mathrm{W}$, Fig. 1). Further foraging characteristics are given in Table 1, as well as in Fig. 2, which provides increment plots of total foraging areas for both breeding and inter-breeding birds.

Activity patterns were recorded for a total of 17 birds (see Table 1). The other 9 individuals were equipped with back-pack loggers, which are unsuitable for temperature-based activity measurements. Birds were recorded landing on the sea at all times of the day, but landing frequency tended to decrease in the morning (but no significant difference between means $\mathrm{p}>0.05$, Fig. 3A). Over $90 \%$ of the intervals spent on the sea lasted for less than $2 \mathrm{~h}$ (Fig. $4 \mathrm{~A}$ ). 
Table 1. Diomedea melanophris. Foraging characteristics of breeding and inter-breeding black-browed albatrosses from the Falkland Islands (mean values \pm standard deviation, along with range and sample sizes). Bold print indicates a significant difference

\begin{tabular}{|c|c|c|c|c|c|c|c|c|c|}
\hline & $\begin{array}{c}\text { Time at } \\
\text { sea } \\
\text { (d) }\end{array}$ & $\begin{array}{c}\text { Foraging } \\
\text { area } \\
\left(1000 \mathrm{~km}^{2}\right)\end{array}$ & $\begin{array}{c}\text { Travel } \\
\text { speed } \\
\left(\mathrm{km} \mathrm{d}^{-1}\right)\end{array}$ & $\begin{array}{l}\text { Foraging } \\
\text { range } \\
(\mathrm{km})\end{array}$ & $\begin{array}{l}\text { Max foraging } \\
\text { range } \\
(\mathrm{km})\end{array}$ & $\begin{array}{c}\text { Total time } \\
\text { on water } \\
(\%)\end{array}$ & $\begin{array}{l}\text { Landings } \\
\qquad\left(\mathrm{d}^{-1}\right)\end{array}$ & $\begin{array}{l}\text { Landing } \\
\text { time } \\
\text { (min) }\end{array}$ & $\begin{array}{c}\text { Work index } \\
\text { (\% max. } \\
\text { distance) }\end{array}$ \\
\hline $\begin{array}{l}\text { Breeding } \\
\text { birds }\end{array}$ & $\begin{array}{c}6.8 \pm 3.0 \\
(2-13) \\
n=26\end{array}$ & $\begin{array}{c}102 \pm 132 \\
(11-643) \\
n=26\end{array}$ & $\begin{array}{c}296 \pm 129 \\
(95-725) \\
n=26\end{array}$ & $\begin{array}{c}691 \pm 330 \\
(232-1357) \\
n=26\end{array}$ & $\begin{array}{c}1163 \pm 621 \\
(415-3078) \\
n=26\end{array}$ & $\begin{array}{c}48 \pm 3 \\
(16-75) \\
n=17\end{array}$ & $\begin{array}{l}13 \pm 6 \\
(9-29) \\
n=17\end{array}$ & $\begin{array}{c}67 \pm 32 \\
(23-147) \\
n=17\end{array}$ & $\begin{array}{l}16 \pm 6 \\
(6-36) \\
n=26\end{array}$ \\
\hline $\begin{array}{l}\text { Inter- } \\
\text { breeding } \\
\text { birds }\end{array}$ & $\begin{array}{c}127.5 \pm 11.7 \\
(114-144) \\
n=6\end{array}$ & $\begin{array}{c}1552 \pm 970 \\
(490-3010) \\
n=6\end{array}$ & $\begin{array}{c}267 \pm 55 \\
(173-327) \\
n=6\end{array}$ & $\begin{array}{c}680 \pm 192 \\
(378-934) \\
n=6\end{array}$ & $\begin{array}{c}1729 \pm 518 \\
(1148-2279) \\
n=6\end{array}$ & $\begin{array}{c}63 \pm 3 \\
(30-76) \\
n=6\end{array}$ & $\begin{array}{c}8.7 \pm 2 \\
(7-12) \\
n=6\end{array}$ & $\begin{array}{c}114 \pm 51 \\
(42-191) \\
n=6\end{array}$ & $\begin{array}{c}27 \pm 6 \\
(17-33) \\
n=6\end{array}$ \\
\hline $\begin{array}{l}\text { Statistical } \\
\text { relevance }\end{array}$ & & $\begin{array}{c}t=8.01 \\
\mathrm{p}<0.001\end{array}$ & $\begin{array}{l}t=0.53 \\
p>0.5\end{array}$ & $\begin{array}{l}t=0.08 \\
p>0.5\end{array}$ & $\begin{array}{c}t=2.07 \\
\mathbf{p}<0.05 \\
(\arcsin \operatorname{trs} \text { ) }\end{array}$ & $\begin{array}{l}t=10.90 \\
\mathbf{p}<\mathbf{0 . 0 0 1}\end{array}$ & $\begin{array}{l}t=1.70 \\
\mathrm{p}>0.05\end{array}$ & $\begin{array}{c}t=2.61 \\
\mathrm{p}<0.02\end{array}$ & $\begin{array}{c}t=4.14 \\
\mathbf{p}<0.005\end{array}$ \\
\hline
\end{tabular}

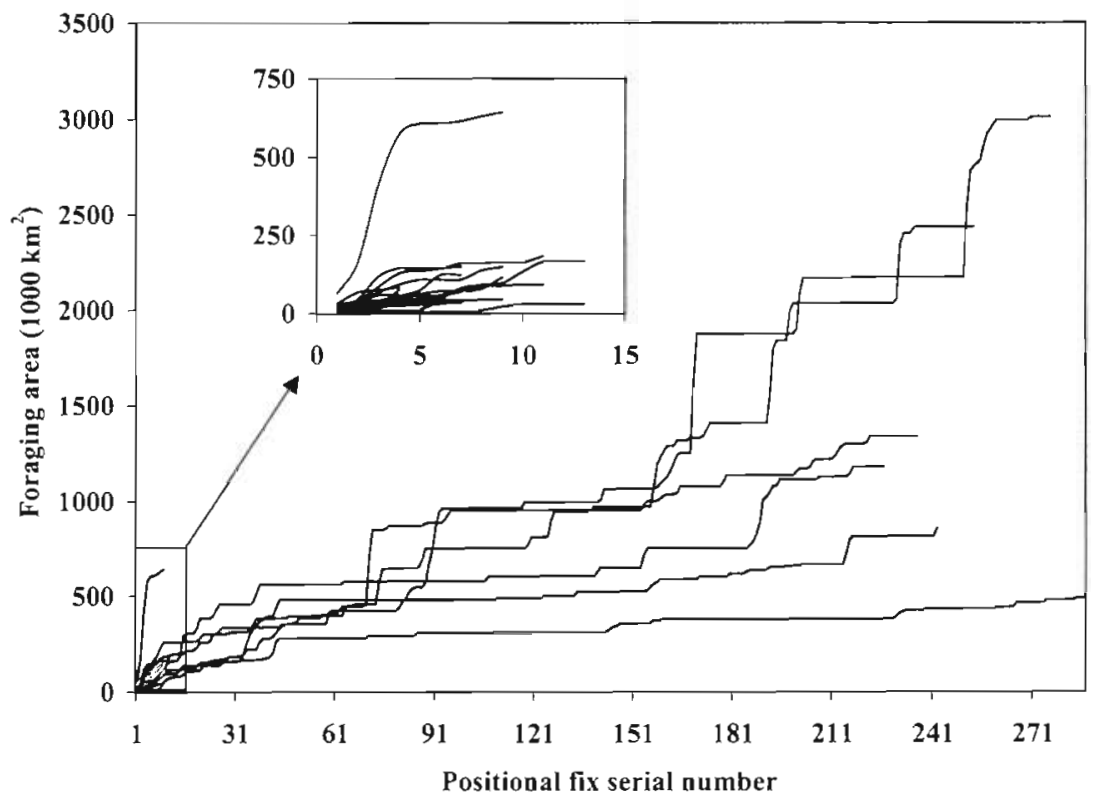

Fig. 2. Diomedea melanophris. Increment plots for individual foraging areas of incubating (inset) and inter-breeding blackbrowed albatrosses from the Falkland Islands

\section{Foraging patterns during the inter-breeding period}

A total of 16 birds was equipped with foot-attached data loggers at the end of the breeding season in April 1997 Upon their return to the breeding site in September 1997, 9 birds were still carrying the logging unit. Some skin abrasion could be noticed in 2 cases when detaching logger and rings from the bird's foot, although this only slightly affected the foot's epidermis and is thus unlikely to result in any permanent lesions. Because the birds studied were not individually marked (apart from carrying the data-logger), it was not possible to tell whether the remaining 7 birds man- aged to detach the logger and foot rings when at sea or did not come back to the breeding site in September. Data from 6 of the 9 loggers recovered was successfully downloaded and analysed (4 from a SBT200 and 2 from a LTD-100). These results are summarised in Table 1. Despite the fact that these 6 birds spent ca 20 times more time at sea than the incubating birds and travelled $33872 \mathrm{~km}$ on average ( $\mathrm{SD}=7200$, range 24912 to $41529 \mathrm{~km}$ ), the oceanic zone utilised by all 6 birds during these 4 mo was very similar to the foraging area recorded for breeding individuals (Fig. 5). Birds from both periods also essentially used the same core foraging area lover $80 \%$ of all position fixes within 45 to $50^{\circ} \mathrm{S}$ and 60 to $70^{\circ} \mathrm{W}$ for inter-breeding 

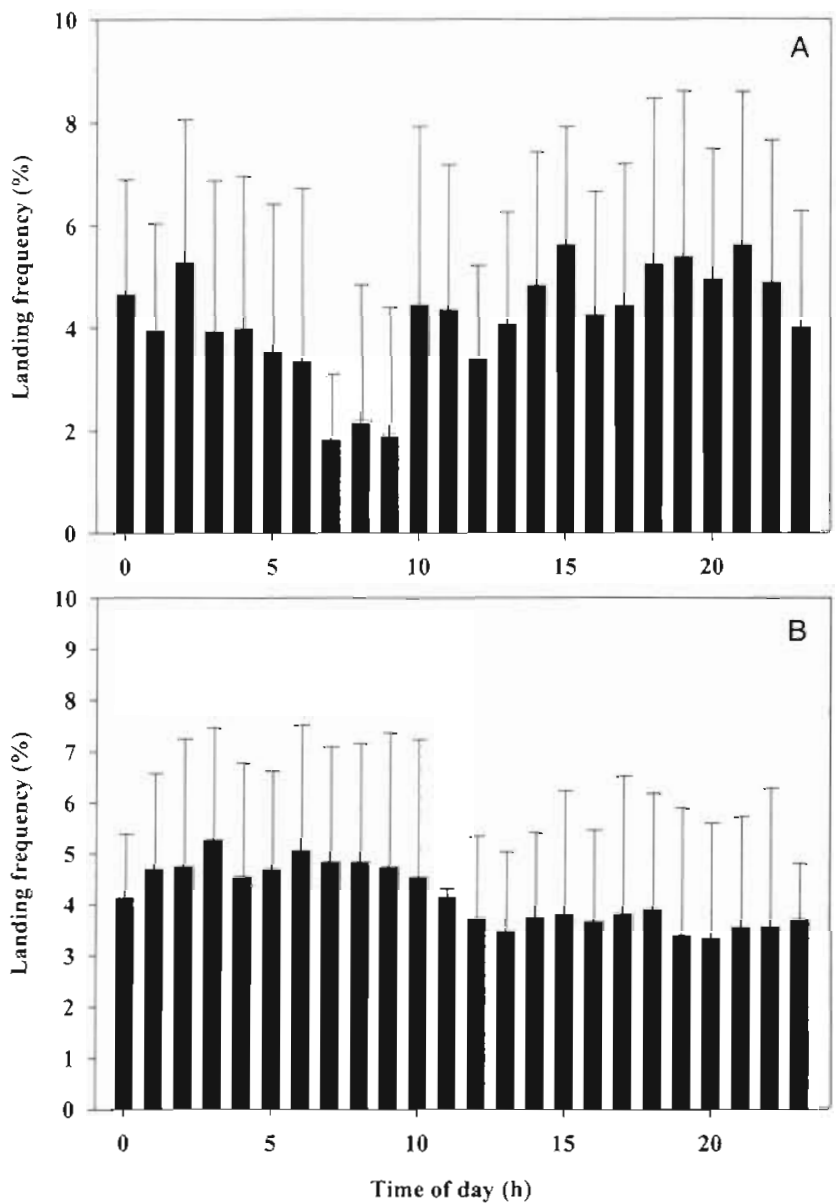

Fig. 3. Diomedea melanophris. Proportion of landing events per $2 \mathrm{~h}$ period as recorded for (A) incubating and (B) interbreeding black-browed albatrosses

birds, Fig. 5), although there was a tendency for interbreeding birds to move southwards in August/September (Figs. 5 \& 9). Moreover, although the mean seaarea covered per bird was substantially higher for over-wintering birds than for breeding individuals (Table 1, Fig. 2), this area was extremely small considering the time spent at sea and the birds' travelling abilities (see 'Discussion'). As for incubating birds, travelling speeds were significantly higher during the last $24 \mathrm{~h}$ of the trip $\left(670 \mathrm{~km} \mathrm{~d}^{-1}, \mathrm{SD}=400\right)$ than during the intermediate part of the trip $\left\{270 \mathrm{~km} \mathrm{~d}^{-}, \mathrm{SD}=70\right.$, $t=2.4, \mathrm{p}<0.05$ ), and there was no significant difference between the average travelling speeds during the first $24 \mathrm{~h}$ of the trip $\left(360 \mathrm{~km} \mathrm{~d}^{-1}, \mathrm{SD}=70\right)$ and the intermediate part of the trip $(t=1.8, p<0.05)$. Other foraging characteristics were also similar to those measured during the incubation phase, except that birds spent a significantly longer period on the water, and consequently spent significantly less time flying than during the breeding season (Table 1). Landing periods were extremely evenly distributed over the day (no signifi-
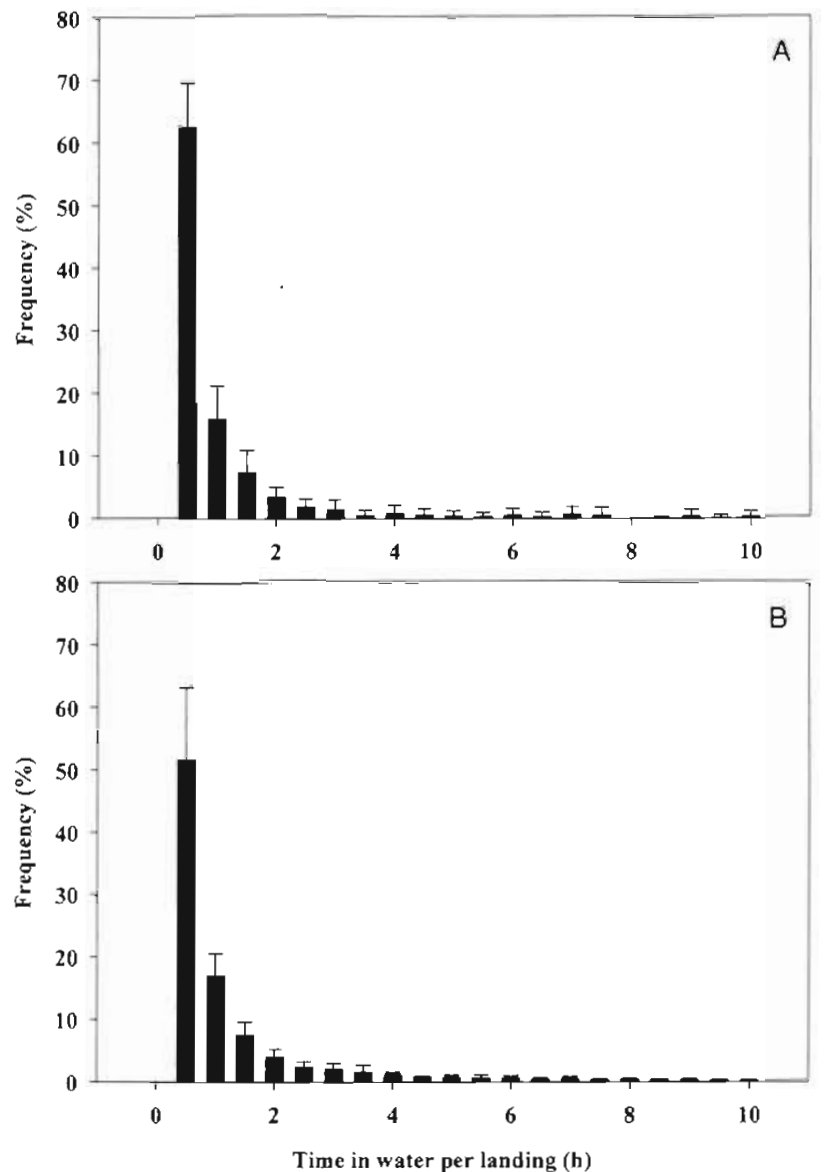

Fig. 4. Diomedea melanophris. Frequency distribution of the time spent at the water surface $(\%)$ during single landing events by $(A)$ incubating and $(B)$ inter-breeding blackbrowed albatrosses

cant difference between means $p>0.5$, Fig. 3B) and lasted in more than $80 \%$ of all cases for $<2 \mathrm{~h}$ (Fig. $4 \mathrm{~B}$ ). The average work index was higher than in incubating birds $(27 \%$, significant differences between individuals $F=14.9, \mathrm{p}<0.001$, see Table 1 ), and maximum distance travelled per day showed major, cyclic variability over time (Fig. 6). This suggests that birds may quickly move between food patches at which they spend more time searching for food.

\section{Fishery data}

According to the fisheries statistics, a total of $797093 \mathrm{t}$ of finfish and $408728 \mathrm{t}$ of squid were taken in the Patagonian Shelf area between October 1996 and September 1997. Within the FICZ, totals of $49444 \mathrm{t}$ of finfish and $180909 \mathrm{t}$ of squid were caught, which represented 6.2 and $44.3 \%$ of the total yield for finfish and squid, respectively. Further details on the chronology of finfish and squid catches for both areas are given in 


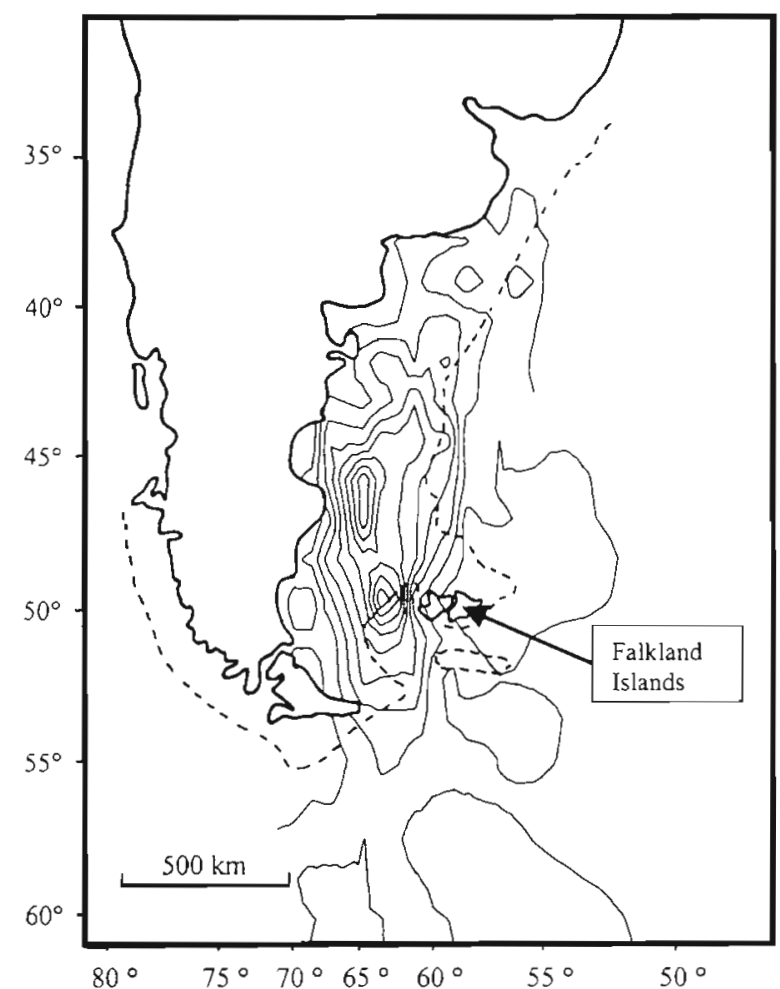

Fig. 5. Diomedea melanophris. Density plot showing the atsea distribution of 6 black-browed albatrosses off South America during the inter-breeding phase (April to September 1997). This topographic representation is based on positional fixes recorded every $12 \mathrm{~h}$. The isolines give the density of positional fixes per surface area (for a contour interval of 3 fixes per unit area). Dotted line gives the $200 \mathrm{~m}$ depth contour

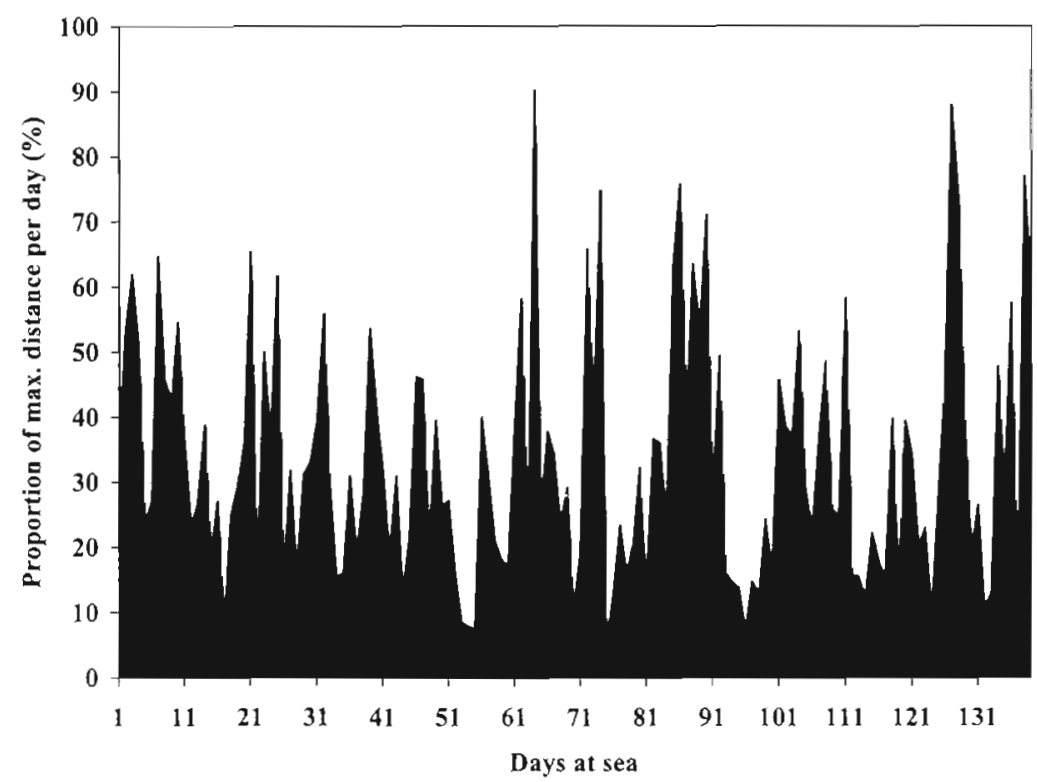

Fig. 6. Diomedea melanophris. Example of the variations of the calculated work index (proportion of the maximum travelling distance covered per day, see 'Methods') throughout a 4 mo offshore journey conducted by a post-breeding black-browed albatross. Note the regular alternation of travelling and foraging phases
Fig. 7A,B. During the first part of the study (incubation phase), there was only minor spatio-temporal overlap between albatrosses' distribution and fishing activities (Fig, 8). In contrast, there was considerable spatial overlap during the inter-breeding period (Fig. 9).

\section{DISCUSSION}

In the case of central-place foragers, optimal foraging theory predicts a major trade-off between energy acquisition (energy content of food load) and energy investment (total foraging costs) with a strong tendency towards foraging area minimisation (Stephen \& Krebs 1986, Houston et al. 1996). This is counter-balanced in colonial central-place foragers by intra-specific competition, which is obviously strongest near the breeding site (Ashmole 1963, Fumess \& Birkhead 1984, Cairns 1989). The overall area utilised by a colonial central-place forager (i.e. a breeding seabird) is thus likely to be substantially smaller than the surface area covered by a free-ranging forager (i.e. an interbreeding individual). The total foraging area considered here clearly depends on the average travelling speed of any given species, and it appears that this theoretical framework has to date mainly been tested in small, captive, passerine birds (Cézilly \& Benhamou 1996). As procellariiforms probably have the greatest foraging ranges of any extant bird (up to $15000 \mathrm{~km}$ in a single foraging trip, Jouventin \& Weimerskirch 1990), our study thus represents one of the largest possible scales for which this simple prediction can be tested (Gaston \& Blackburn 1996).

Surprisingly, and despite the fact that mean individual foraging area was significantly larger outside the breeding season than during the incubation period of black-browed albatrosses (Table 1), inter-breeding birds did not travel farther away from their breeding site on West Falklands than did incubating individuals and seldom left the Patagonian Shelf area (with the exception of a general movement towards the Antarctic Peninsula in late August 1997 [see Figs. 1, 5 \& 9]). Moreover, individual foraging areas of inter-breeding birds were occasionally even smaller than the area covered by an incubating individual recorded during a single 5 d trip (0.65 million $\mathrm{km}^{2}$, see Fig. 2). This was rather unexpected, because the overall distribution range of black-browed albatrosses is the widest among Southern Hemisphere albatrosses (Tickell 1993), and because the birds studied had enough time to fly almost 3 times around the 

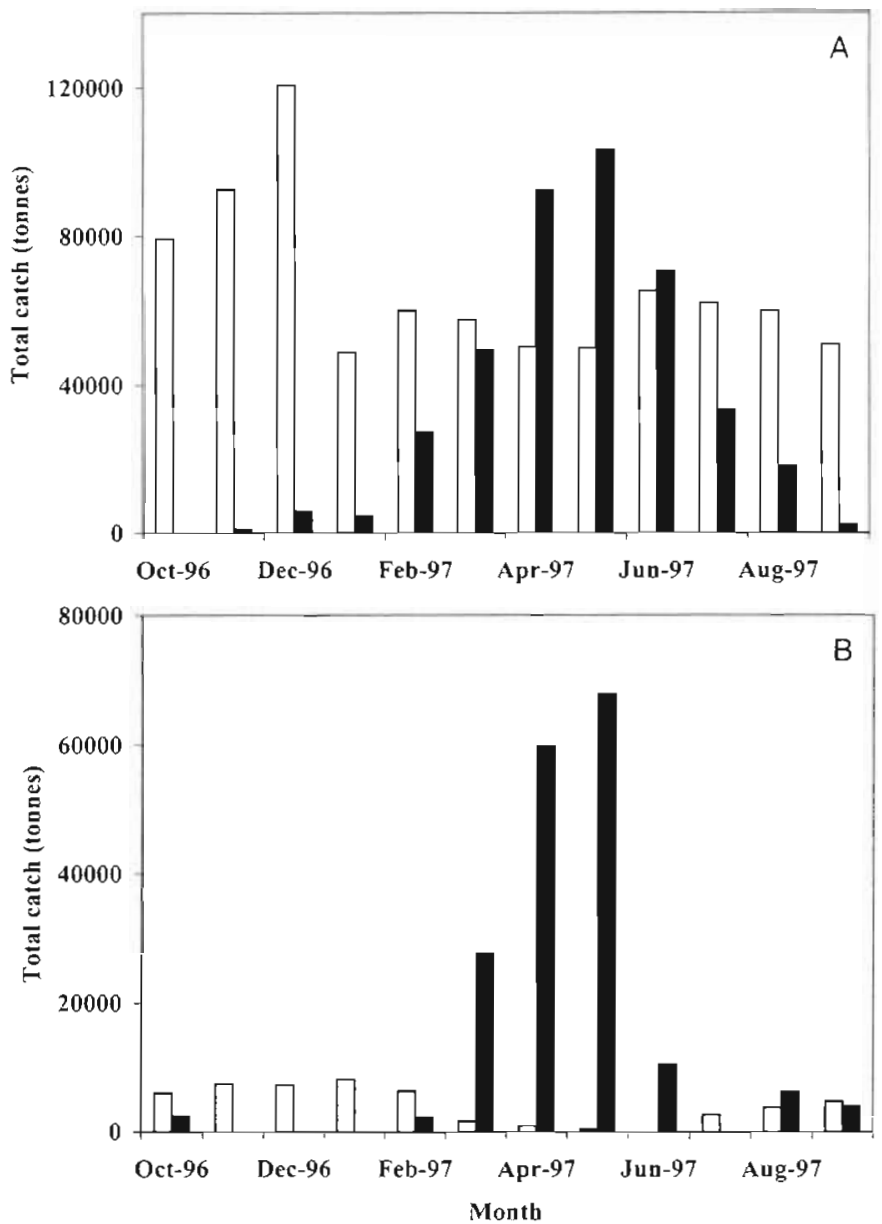

Fig. 7. Diomedea melanophris. (A) Monthly total catch (tonnes) for squid (solid bars) and finfish (open bars) during the study period in the Patagonian Shelf area. (B) Monthly total catch (tonnes) for squid (solid bars) and finfish (open bars) during the study period within the Falkland Islands Management and Conservation zone (FICZ)

earth along the equator during the inter-breeding season, or could have potentially visited the highly productive Benguela upwelling system (a $10 \mathrm{~d}$ journey), as their South Georgian conspecifics often do (Tickell 1976). We suggest that these results are linked to the facts that: (1) the breeding birds studied had a particularly wide foraging area and (2) inter-breeding individuals did not make full use of their travelling capacity.

In the first case, previous studies carried out on black-browed albatrosses from the Crozet Islands (Weimerskirch et al. 1986, 1988), Kerguelen (Cherel \& Weimerskirch 1995), South Georgia (Veit \& Prince 1997) and Campbell Island (Waugh et al. 1999), showed that breeding individuals are typically linked to shelf waters (with maximum foraging ranges $<1000 \mathrm{~km}$ ), although they regularly undertake more extended offshore trips to reach the Antarctic Polar

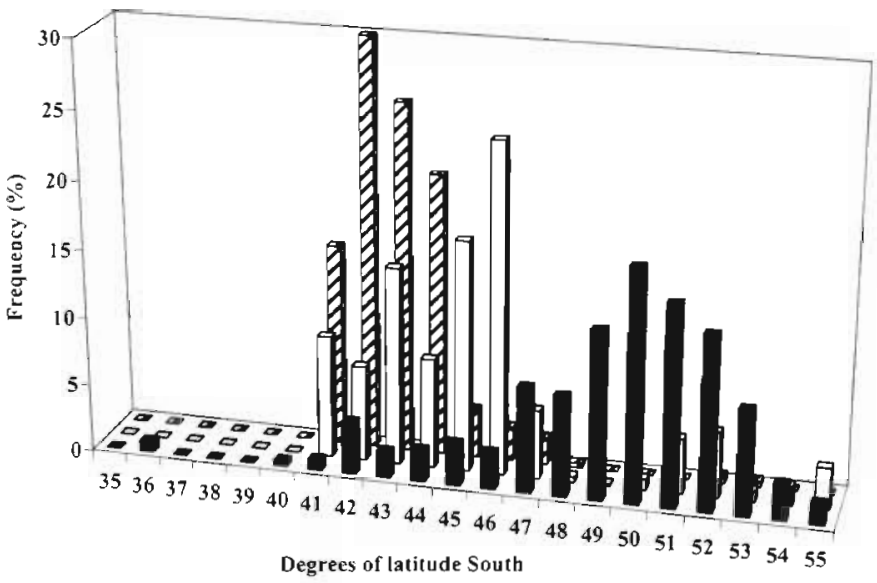

Fig. 8. Diomedea melanophris. Comparison of the frequency distribution of positional fix density for 26 foraging trips of black-browed albatrosses during the incubation phase (October and November 1996 [solid bars| with the frequency distribution of total fish catches [tonnes] [open bars] and the frequency distribution of total squid catches [tonnes] [hatched bars]) in relation to degrees of latitude

Front (maximum foraging range of ca $2000 \mathrm{~km}$, Waugh et al. 1999). Nonetheless, a strong limiting factor appears to be the surface area of adjacent shelf areas, which are in all cases restricted to the vicinity of these islands. In the case of black-browed albatrosses feeding over the Patagonian Shelf, the area of suitable foraging habitat is certainly not particularly limiting (1.4 million $\mathrm{km}^{2}$, the largest shelf area in the Southern Hemisphere) and enables breeding birds to enlarge their foraging area in order to reduce intra-specific competition. It is thus not surprising that black-browed albatrosses breeding on the West Falklands displayed the greatest foraging ranges ever measured for this species (Table 1). This strategy is presumably supported by the remarkably low travelling costs of blackbrowed albatrosses (Bevan et al. 1995), related to their capacity to use dynamic-soaring to reduce flight costs (Sachs 1993).

Conversely, the unusually large size of potential feeding grounds may also explain the relatively restricted foraging area of the inter-breeding birds. Over $70 \%$ of the world's population of black-browed albatross (1.2 million individuals according to Thompson \& Rothery 1991) breed on the Falkland Islands (Thompson \& Riddy 1995), and our results thus suggest that the Patagonian Shelf area holds sufficient resources to support ca 800000 of these large avian predators (mean mass of black-browed albatrosses is $3.6 \mathrm{~kg}$. Warham 1990) throughout the year, so that post-breeding dispersal does not drive adult birds to visit other shelf areas. 

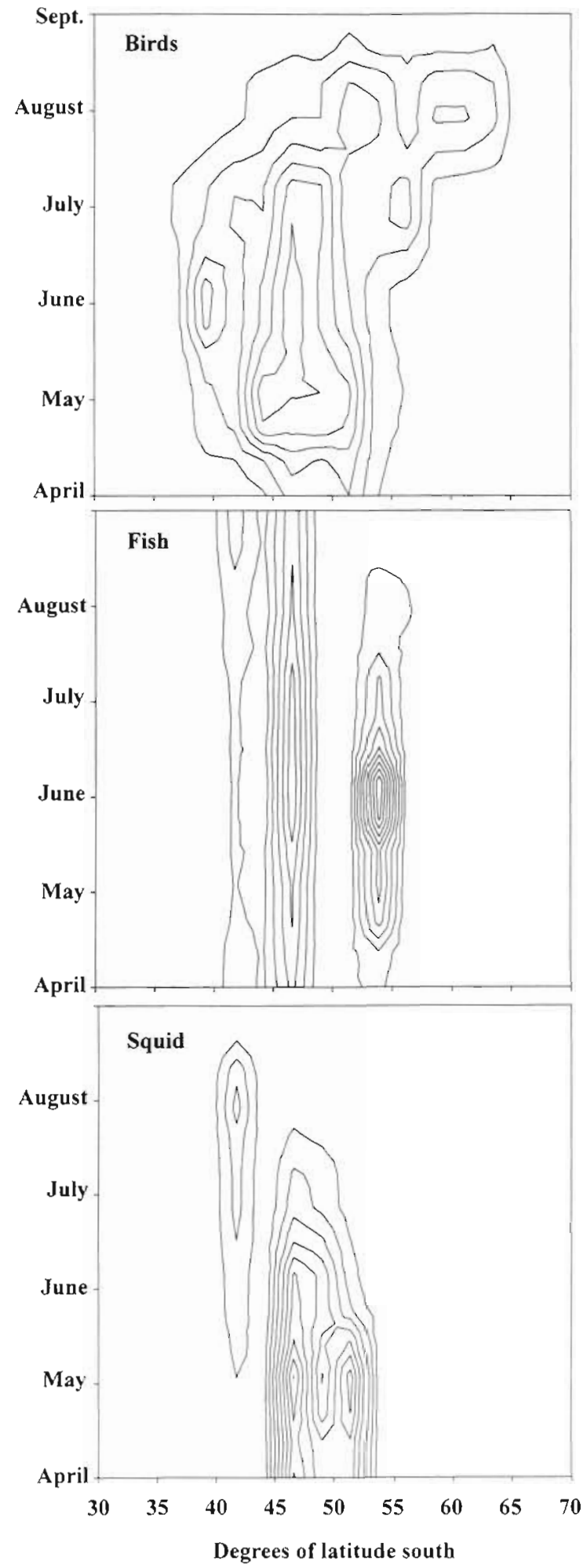

Fig. 9. Diomedea melanophris. Comparison of the density distribution of positional fixes for 6 black-browed albatrosses during the inter-breeding season 1997 (for a contour interval of 3 fixes) with the concurrent density distribution of total fish catch and total squid catch (both for a contour interval of 3 tonnes) within the Patagonian Shelf area
Altogether, foraging habits in incubating and interbreeding black-browed albatrosses from New Island are extremely similar. They move quickly either between the nest and a main foraging area (incubation) or between feeding patches (inter-breeding phase, Fig. 6) at which they spend more time searching for prey. They do so by landing on the water surface for short periods at any time of the day (Figs. $3 \& 4$ ). The only significant difference in their behaviour appears when calculating the work index. Inter-breeding birds tend to travel more than breeding individuals, which is surprising, as incubating birds may be thought to fly longer distances when commuting between the nest and the feeding grounds. Moreover, although great importance has been given to diurnal rhythms in foraging pelagic birds and especially albatrosses (Warham 1990), inter-breeding birds do not seem to link their behavioural patterns to a 24 h cycle. Rather, they seem to alternate periods of great activity with less mobile phases (Fig. 6). This suggests extended patchiness in the distribution of their prey (Bell 1991).

There are several potential limitations to our findings. First, we only recorded the foraging behaviour of incubating birds and not that of birds during the chickrearing phase. According to previous work performed by Stauffacher (1979) on black-browed albatrosses breeding on New Island (our study site), the length of the foraging trips decreases during the breeding cycle to ca $4 \mathrm{~d}$ on average during the late chick-rearing period. With an average travelling speed of ca $300 \mathrm{~km}$ $\mathrm{d}^{-1}$ (Table 1), this suggests a foraging range of only $600 \mathrm{~km}$ for a bird flying in a straight line between the breeding and feeding sites, which is similar to mean values recorded in this study. However, the overall home range of provisioning birds is then likely to be substantially smaller than that of incubating or interbreeding individuals. Second, although our study is, to the best of our knowledge, the first to record the at-sea behaviour of albatrosses throughout the inter-breeding phase, and the above findings are supported by longterm ring recoveries and sightings summarised in Tickell $(1967,1976,1993)$, it has been shown that birds from different breeding sites within the Falklands may display different feeding preferences (Thompson 1992), suggesting potentially different dispersal patterns. Third, the considered albatross population includes a large proportion of immature and interbreeding birds, whose distribution range is likely to be much wider than that of breeding birds (Tickell 1976, Warham 1990).

Nonetheless, our data suggest that black-browed albatrosses breeding on the West Falklands are tightly linked to the Patagonian Shelf area throughout the year (Figs. $1 \& 5$ ). These findings have important conservation implications. The fact that black-browed 
albatrosses from the Falkands seem to favour the Patagonian Shelf area throughout the year emphasises the particularly high productivity of this coastal region, which also provides food for large numbers of other marine top-predators, including Magellanic penguins (Spheniscus magellanicus, 3.6 million individuals, Williams 1995) and sea lions (Otaria byronia, 300000 individuals, Campagna 1985). This productivity results from the fact that the Patagonian Shelf is large and relatively shallow, and thus exhibits intense benthicpelagic coupling (Marcus \& Boero 1998). Nutrient remobilization is furthermore enhanced by numerous front and upwelling systems (Peterson 1992). However, this also demonstrates the overwhelming impact that a reduction of food availability or quality may have on these populations, and our results have to be considered in the light of the recent and rapid development of industrial fisheries in the Patagonian Shelf area (FAO 1999). These fishing activities can be divided into 3 categories (FAO 1999): (1) Trawlers mainly targeting hake (Merluccius hubbsi \& M. australis) and blue whiting (Micromesistius australis), (2) Jiggers harvesting squid (Illex argentinus and Loligo gahi) and (3) Long-liners fishing patagonian toothfish (Dissostichus eleginoides).

In this sea area, total catches increased rapidly between the 1950s (170000 tonnes in 1950) and the 1980 s (2.4 million tonnes in 1987) as a result of increased international fishing effort (FAO 1999). Throughout the 1980s, squid became the main target species, the bulk of the catch being taken within the FICZ $(240 \mathrm{~km}$ around the Falklands). After a slight decrease during the 1990s, the present, rapid development of long-line fishing for patagonian toothfish appears to take total catches over the maximum level recorded in 1987 (FAO 1999).

There are 3 potential direct interactions between these human activities and black-browed albatrosses (see Thompson 1992): (1) Fish refuse (bycatch, offal and discards) produced by fisheries may provide additional food for seabirds, (2) overfishing may detrimentally reduce the availability of particular fish species important for the birds and (3) seabirds attracted by baited fishing hooks may get caught and drowned.

Previous work analysed the interactions of human fisheries and black-browed albatrosses within the FICZ (Thompson 1992, Thompson \& Riddy 1995) and suggested that, although waste produced by squid and finfish fishing vessels may contribute 10 to $15 \%$ and $4.4 \%$, respectively, of black-browed albatrosses' energy requirements, albatrosses were nonetheless likely to suffer from the consequences of overfishing in the long term. These investigations were restricted to the FICZ and to the chick-phase (January to April). Results from our study appear as useful complements to Thompson's findings, and give a wider perspective to the problem: we confirm that fishing units and albatrosses overlap in time and space when tracking prey stocks (Fig. 9), but major hotspots do not appear within the FICZ (Figs. 1 \& 5), nor during the incubation phase (Fig. 8). Rather, a zone of particular importance is situated northwest of the Falkland Islands, and the main overlap between albatrosses and fisheries occurs in May (Fig. 9). Thompson's concerns of major competition for fish and squid between fisheries and albatrosses may thus be enlarged to the inter-breeding phase. Moreover, current development of toothfish fisheries in the Patagonian shelf area and the related extended activities of long-liners add a further point of concern, as it is known that such activities cause high levels of seabird 'bycatch' (Weimerskirch et al. 1999). Long-lining has a particularly strong detrimental influence on albatross populations, as their extremely low reproductive rates do not allow them to compensate for any man-induced increase of their mortality rate (Weimerskirch \& Jouventin 1986, Prince et al. 1994, Brothers et al. 1999).

Acknowledgements. This study was funded by the Deutsche Forschungsgemeinschaft (Grant Wi 1023/2-1 to R.P.W. and J. Plötz) and by the Institut für Meereskunde Kiel through Dieter Adelung. Grateful thanks are due to Mike Bingham, Jeremy Smith \& Hay from Falkland Conservation, to Annie and Tom Chater, Ian Strange, Mary-Anne Lea, Sam Thalmann and Ann for their help and hospitality during field work. CEFAS Lowestoft and LOTEK provided us with LTD-100 dataloggers and D.G. thanks Trevor Storeton-West. Graham Moore, Matthew Eagle and Julian Metcalfe for their generous help. Thanks also to Andy Webb, Denise Wright and Robert Kenward from the Institute of Terrestrial Ecology for computing advice and support. All fisheries data were kindly provided by the Falkland Islands Government through John Barton and Ryszard Grzebielec and by the Instituto Nacional de Investigaciones y Desarollo Pesquero, Mar. Del Plata through Ramiro Sanchez. Special thanks to Henri Weimerskirch for helping D.G. to prepare this field trip and for his hospitality.

\section{LITERATURE CITED}

Ashmole NP (1963) The regulation of numbers of tropical oceanic birds. Ibis 103b:458-473

Bell WJ (1991) Searching behaviour. The behavioural ecology of finding resources. Chapman and Hall, London

Bevan RM, Butler PJ, Woakes AJ, Prince PA (1995) The energy expenditure of free-ranging black-browed albatrosses. Philos Trans R Soc Lond Biol Sci 350:119-131

Block B, Dewar H, Farwell C, Prince ED (1998) A new satellite technology for tracking the movements of Atlantic bluefin tuna. Proc Natl Acad Sci 95:9384-9389

Bost CA, Georges JY, Guinet C, Cherel Y, Pütz K, Charrassin JB, Handrich Y, Zorn T, Lage J, Le Maho Y (1997) Foraging and food intake of satellite-tracked king penguins during the austral summer at Crozet Archipelago. Mar Ecol Prog Ser 150:21-33 
Bowen WD (1997) Role of marine mammals in aquatic ecosystems. Mar Ecol Prog Ser 158:267-274

Brothers N, Gales R, Reid T (1999) The influence of environmental variables and mitigation measures on seabird catch rates in the Japanese tuna longline fishery within the Australian Fishing Zone, 1991-1995. Biol Conserv 88: 85-- 101

Burns JM, Castellini MA (1998) Dive data from satellite tags and time-depth recorders: a comparison in Weddell Seal pups. Mar Mamm Sci 14:750-764

Butler PJ, Jones DR (1997) Physiology of diving of birds and mammals. Physiol Rev 77:837-899

Cairns DK (1.989) The regulation of seabird colony size: a hinterland model. Am Nat 134:141-146

Campagna C (1985) Suuthern sea lions. Mar Mamm Sci 1:340

Cézilly F, Benhamou $S$ (1996) Les stratégies optimales d'approvisonnement. Rev Ecol Terre Vie 51:43-85

Cherel Y, Weimerskirch $H$ (1995) Seabirds as indicators of marine resources: black-browed albatrosses feeding on ommastrephid squids in Kerguelen waters. Mar Ecol Prog Ser 129:295-300

Croll DA, Tershy BR, Hewitt RP, Demer DA, Fiedler PC, Smith SE, Armstrong W, Popp JM, Kiekhefer T, Lopez VR, Urban $J$, Gendron D (1998) An integrated approach to the foraging ecology of marine birds and mammals. Deep-Sea Res Part II Top Stud Oceanogr 45:1353-1369

Croxall, JP (1995) Remote-recording of foraging patterns in seabirds and seals for studies of predator-prey interactions in marine systems. In: Skjoldal HR, Hopkins C, Erikstad $\mathrm{KE}$, Leinaas HP (eds) Ecology of fjords and coastal waters. Elsevier Science BV, Amsterdam, p 429-442

FAO (Food and Agriculture Organization) (1999) Review of the state of world fishery resources: marine fisheries. 6 . Southeast Atlantic. Marine Resource Service, Fishery Resources Division, Fisheries Department, FAO, Rome; available at http://www.fao.org/WAICENT/FAOINFO/FISHERY/pubV/circular/c920/area41t.htm

Field CB, Behrenfeld MJ, Randerson JT, Falkowski P (1998) Primary production of the biosphere: integrating terrestrial and oceanic components. Science 281:237-240

Furness RW, Birkhead TR (1984) Seabird colony distributions suggest competition for food supplies during the breeding season. Nature 311:655-656

Gales NJ, Mattlin RH (1997) Summer diving behavior of lactating New Zealand sea lions, Phocarctos hookeri. Can J Zool 75:1695-1706

Gaston KJ, Blackburn TM (1996) Range size-body size relationships: evidence of scale dependence. Oikos 75: 479-485

Goni R (1998) Ecosystem effects of marine fisheries: an overview. Ocean Coast Manag 40:37-64

Greenwood PH (1992) Are the major fish faunas well-known? Neth J Zool 42:131-138

Haeckel E (1866) Generelle Morphologie der Organismen. Allgemeine Grundzüge der organischen Formen-Wissenschaft, mechanisch begründet durch die von $C$. Darwin reformierte Descendenz-Theorie, 2 Bd. G Reimer, Berlin

Hooker SK, Baird RW (1999) Deep-diving behaviour of the northern bottlenose whale, Hyperoodon ampullatus. Proc R Soc Lond B 266:671-676

Houston AI, Thompson WA, Gaston AJ (1996) The use of time and energy budget model of a parent bird to investigate limits to fledging mass in the thick-billed murre. Funct Ecol 10:432-439

Jouventin P, Weimerskirch H (1990) Satellite tracking of wandering albatrosses. Nature 343:746-748

Kaplan ED (ed) (1996) Understanding GPS: principles and applications. Artech House Inc, Norwood, MA
Kooyman GL, Drabek CM, Elsner R, Campbell WB (1971) Diving behavior of the emperor penguin Aptenodytes forsteri. Auk 88:775-795

Larkin PA (1996) Concepts and issues in marine ecosystem management. Rev Fish Biol Fish 6:139-164

Luschi P, Hays GC, Del Seppia C, Marsh R, Papi F (1998) The navigational feats of green turtles migrating from Ascension Island investigated by satellite telemetry. Proc R Soc Lond B 63:2279-2284

Marcus $\mathrm{NH}$, Boero $\mathrm{F}$ (1998) Minireview: the importance of benthic-pelagic coupling and the forgotten role of life cycles in coastal aquatic systems. Limnol Oceanogr 43 $763-768$

McConnell BJ, Fedak MA (1996) Movements of southern elephant seals. Can J Zool 74:1485-1496

Nihoul JCJ (1998) Modelling marine ecosystems as a discipline in earth science. Earth-Sci Rev 44:1-13

Pennycuick CJ (1989) Bird flight performance. A practical calculation manual. Oxford University Press, Oxford

Peterson RG (1992) The boundary currents in the western Argentine Basin. Deep-Sea Res 39:623-644

Prince PA, Rothery P, Croxall JP, Wood AG (1994) Population dynamics of black-browed and grey-headed albatrosses Diomedea melanophris and D. chrysostoma at Bird Island. South Georgia. Ibis 136:50-71

Sachs G (1993) Minimaler Windbedarf für den dynamischen Segelflug der Albatrosse. J Ornithol 134:435-445

Sagar PM, Weimerskirch H (1996) Satellite tracking of southern buller's albatrosses from the Snares, New Zealand. Condor 98:649-652

Stauffacher M (1979) Die Brutbiologie des SchwarzbrauenAlbatros (Diomedea melanophris Temminck) auf den Südatlantischen Falkland Inseln. Unpubl. MSc thesis, University of Basel

Stephen DW, Krebs JR (1986) Foraging theory. Princeton University Press, Princeton, NJ

Taylor A., Planque B (1998) Long-term changes in zooplankton and the climate of the North Atlantic. J Mar Sci 55: $644-654$

Thompson KR (1992) Quantitative analysis of the use of discards from squid trawlers by black-browed albatrosses Diomedea melanophris in the vicinity of the Falkland Islands. Ibis 134:11-21

Thompson KR, Riddy MD (1995) Utilization of offal and discards from 'finfish' trawlers around the Falkland Islands by the black-browed Albatross Diomedea melanophris. Ibis 137:198-206

Thompson KR, Rothery P (1991) A census of the black-browed albatross Diomedea melanophris population on Steeple Jason Island, Falkland Islands. Biol Conserv 56:39-48

Tickell WLN (1967) Movements of black-browed and greyheaded albatrosses in the South Atlantic. Emu 66:357-367

Tickell WLN (1976) The distribution of black-browed and grey-headed albatrosses. Emu 76:64-68

Tickell WLN (1993) Atlas of Southern Hemisphere albatrosses. Bull Pac Seabird Grp 20:20-38

Veit RR, Prince PA (1997) Individual and population level dispersal of black-browed albatrosses Diomedea melanophris and grey-headed albatrosses $D$. chrysostoma in response to Antarctic krill. Ardea 85:129-134

Walsh DW, Everson JP (1999) An assessment of light-based geoposition estimations from archival tags. Can J Fish Aquat Sci 56:1317-1327

Warham $J$ (1990) The petrels. Their ecology and breeding systems. Academic Press, London

Waugh SM, Weimerskirch $\mathrm{H}$, Cherel Y, Shankar U, Prince PA, Sagar PM (1999) Exploitation of the marine environment 
by two sympatric albatrosses in the Pacific Southern Ocean. Mar Ecol Prog Ser 177:24:3-254

Weimerskirch $H_{1}$ Jouventin P (1986) Population dynamics of the wandering albatross, Diomedea exulans, of the Crozet Islands: causes and consequences of the population decline. Oikos 49:315-322

Weimerskirch $H_{1}$ Robertson G (1994) Satellite tracking of light-mantled sooty albatrosses. Polar Biol 14:123-126

Weimerskirch H, Jouventin. P, Stahl JC (1986) Comparative ecology of the six albatross species breeding on the Crozet Islands. Ibis 128:195-213

Weimerskirch H, Bartle JA, Jouventin P, Stahl JC (1988) Foraging ranges and partitioning of feeding zones in three species of southern albatrosses. Condor 90:214-219

Weimerskirch $\mathrm{H}$, Catard A, Prince PA, Cherel Y, Croxall JP (1999) Foraging white-chinned petrels Procellaria aequi-

Editorial responsibility: Otto Kinne (Editor), Oldendorf/Luhe, Germany noctialis at risk: from the tropics to Antarctica. Biol Conserv $87: 273-275$

Williams TD (1995) The penguins. Spheniscidae. Bird families of the world. Oxford University Press, Oxford

Wilson RP, Weimerskirch H, Lys P (1995) A device for measuring seabird activity at sea. Avian. Biol 26:172-175

Wilson RP, Pütz K, Peters G, Ropert-Coudert Y (1997) Long-term attachment of transmitters and recording devices to penguins and other seabirds. Wildl Soc Bull 25 $101-106$

Wilson RP, Rees WG, Lage J, Pütz K, Kierspel MA, Cooper J, Bost CA, Scolaro JA, Culik BM (in press) Determination of seabird position using changes in light intensity. Proc V Eur Conf Wildl Telemetry

Zavalaga CB, Jahncke J (1997) Maximum dive depths of the Peruvian diving-petrel. Condor 99:1002-1004

Submitted: July 21, 1999; Accepted: October 26, 1999 Proofs received from author(s): March 20, 2000 